\title{
THE EXPRESSIONS OF FREEDOM AND RESISTANCE IN GUNS N' ROSES' APPETITE FOR DESTRUCTION
}

\author{
Nizarur Rahman \\ e-mail: rurahman@gmail.com \\ Nur Saktiningrum \\ Universitas Gadjah Mada \\ e-mail: saktiningrum@ugm.ac.id
}

\begin{abstract}
Music and song lyrics are artistic works for people from any social group to listen to and read. Song lyrics have been situated in various social contexts. Social realities or circumstances, for example, have often been the source of inspiration for song lyrics. This kind of social aspect is apparent in Guns N' Roses' album Appetite for Destruction. The album presents songs with lyrics that portray various social and cultural issues in contemporary society. Through the stories of survival from the physical and mental abuse since childhood, the portrayal of those issues represents the freedom of expression and resistance. Freedom and resistance are a response to abusive behavior and social establishment. This kind of response represents the attitude demonstrated by subculture groups. The present article studies the song lyrics in Appetite for Destruction with the above mentioned topic. The topic is discussed using John Rowe's postnationalist approach and analyzed using Charles Sanders Peirce's semiotic method. The discussion also draws on the concept of subculture as described by Dick Hebdigie. The primary data are the words and sentences in the album that signify expressions of freedom and resistance. The study led to the finding that the album reveals freedom and resistance from the perspective of the victims of physical and mental abuse since childhood. The spirit of freedom and resistance is their anchor throughout their survival from abuses and pitfalls in society. It also found that the song lyrics describe the social realities of subculture groups with the same spirit in surviving life predicaments and the social establishment.
\end{abstract}

Keywords: song lyrics; resistance; expression of freedom; abuse; Appetite for Destruction

DOI : https://doi.org/10.22146/rubikon.v6i2.61491

Available at https://jurnal.ugm.ac.id/rubikon/article/view/61491

This work is licensed under a Creative Commons Attribution-ShareAlike 4.0 International License 


\section{INTRODUCTION}

Music and song lyrics are artistic works for people from any social group to listen to and read. Music comes in various genres such as rock, jazz, country, and blues, but it is the song lyrics thatcarry stories reflecting social realities. For example, the music genre of rock $\mathrm{n}$ roll in the USA, which was pioneered by Elvis Presley and Chuck Berry in 1950, emerged from certain social background (Star, 2006). In its early development, there was a type of American rock $\mathrm{n}$ roll called rockability. It combined rhythm and blues with country music and was played with backbeat sound. Song lyrics written for this type were mostly teachings of life.

Elvis Presley became the first white American to introduce rockability through songs that he composed in 1951. Rockability has its own style of blending musical instruments and vocal harmonies. Elvis Presley considered rock $\mathrm{n}$ roll, together with its subgenre, rockability, as an alternative musical style that could play a role of an evolutionary step in the progress of music genres (Lornell, 2012).

The presence of rock $\mathrm{n}$ roll genre is inseparable from the diversity of the social backgrounds it represents such as African, American, Hispanic, and Asian. In this case, African American music groups are particularly unique in their skill of creating music and lyrics that are closely related to daily life (Koskof, 2005). They have made significant contribution in American music with their creation of socially contextual song lyrics. African American musicians are accustomed to tell the problems in their daily life through their lyrics. This is why music is one of important parts of daily life for African
Americans. In fact, social realities can be considered as the very basis on which song lyrics are created.

Musicians write lyrics that allude to the daily life of American society. Song lyrics have been a means of expressing criticism about particular social conditions in America or circumstances that put pressure on the society such as poverty, lack of freedom, and industrialization. Song lyrics are also a liberating mass medium for cultural expression. They can be a channel for emotional expression that is cultural in nature. In turn, they are presented as a cultural product that is accessible for listeners from different social and cultural backgrounds. Song lyrics and music genresas forms of popular culture intertwine with other forms of popular culture, e.g. fashion that is inspired by a specific genre such as black overall.

One of distinctive genres that contribute to musical popular culture is heavy metal. Heavy metal genre developed in 1980s with different characteristics of movement and appearance from other music genres (Purcell, 2003). At first glance, it is almost similar to rock $\mathrm{n}$ roll. Indeed they have similarities in their use of musical instruments and in the ways their fans dress, but heavy metal (hardcore) has a deeper and heavier sound than rock $\mathrm{n}$ roll. Nevertheless, both of them are presented with song lyrics that represent much of American social and cultural life. They tell something about circumstances or problems in American society from both individual and group perspectives. Many of the lyrics are meant for resistance to social injustice from the American majority.

According to Edward Taylor, culture and civilization in an ethnographic sense are 
complex issues that include knowledge, beliefs, arts, morals, laws, customs, and habits of people from different communities (Moore, 2009). Human behavior is a reflection of the culture of the community itself. Humans create beliefs, moral principles, customs, and laws according to their own worldviews. Culture is closely related to human behavior, both inside and outside. Humans can freely express new thoughts according to their beliefs through song lyrics. The messages represent various American cultural groups. Many of the messages are cultural and social expressions that are related to present-day issues such as lack of freedom and social inequality.

Issues related to the search for freedom have become part of cultural realities that can be explored through the lyrics of rock $\mathrm{n}$ roll songs. The search for freedom in these lyrics also reflects different influences of social groups. Social groups that are associated with specific music genres often reflect social gaps. Punk communities as social groups, for example, are usually marginalized by the whitemajority. They tend to be looked down and considered dirty and bad-mannered (Hebdige, 1979). In reality, they look unorganized as musical bands and as spectators. In a similar pattern, fashion style and lyrics of rock $\mathrm{n}$ roll songs with punk influence are seen as rough, vulgar, and even brutal. They seem to share many characteristics with subcultures. In fact, most of their members are young people, just like fans of hardcore and rock $\mathrm{n}$ roll. Subcultures tend to suggest secret identity and hidden meanings (Rahma, 2017).

The song lyrics in this article need to be examined with a suitable research method that supports theoretical and systematic interpretation of the data as well as help the researcher provide clear explanations for the readers. For this purpose, qualitative method is usedin the study. Qualitative method is applied in data collection, data analysis, and interpretation of meanings (Creswell, 2009). In other words, the study of the song lyrics in Guns N' Roses' Appetite for Destructionin this article was conducted in three stages as a qualitative research.

This research also applies Postnational theory to examine how the expression of cultural freedom is signified in the song lyrics under study. The focus of the analysis is on the ways the lyrics suggest the ideas related to the search for freedom for people in general as members of society. The discussion includes conflicts that arise from gaps between social classes. Social-class-related issues are often associated with other issues that are related to race, ethnicity, and gender (Rowe, 2000).

Semiotics based on Pierce is divided into three. These divisions are based on the category objects that are used, namely icons, indexes, and symbols. These three categories have different roles and purposes, but there is also the synchronization between them. Pierce said that the symbol is the involvement of human thought and science of objects and their surroundings (Spinks, p. 52). It is the basis that semiotics has existed since humans were born, but cannot yet be academically proven. Pierce explains and divides the process of object representation through his theory as follows.

The emergence of American subcultures in some countries contributes to the development of American Studies. Subcultures have become one of important subjects in the studies of American culture. John Rowe states that American Studies is an interdisciplinary 
thinking about American experience (Rowe, 2000).

Studying American cultures in the USA may lead to the assumption that the United States is a model of democratic nation for other nations to emulate (Rowe, 2000). It implies that American Studies has opened a chance for other countries to observe American society and culture. This discipline has been expanded to include many more areas of study such as minority, ethnicity, race, and women's studies with global scope, since American society and culture have been largely shaped by immigrants throughout its history.

Guns N' Roses'Appetite for Destruction presents 12 songs with lyrics that represent American social and cultural issues. Guns N' Roses said that it is their best-selling album in the history of American rock $\mathrm{n}$ roll (Stenning, 2009). Its rise to popularity had boosted the band's popularity as well. This album is worthy of research in the area of American cultural expression that examine how social issues are represented in song lyrics. Besides, the issues portrayed through the lyrics are still relevant today.

\section{DISCUSSION}

\section{Youths' Free Lifestyles}

Every social group in the US generally has their own style of expressing themselves in society as a sense of freedom of expression. They strongly support the idea of being free in many aspects of their life. They demand the freedom to express their opinion of and attitude towards what they have experienced. In fact, a lot of youngsters in the US have a free lifestyle and are reasonably observant of recent social phenomena.Their experiences have motivated them to choose their own way of living their life. The following excerpt "Paradise City" reveals the idea:

Take me down to the paradise city Where the grass is green and the girls are pretty

Take me home (oh won't you please take me home)

Take me down to the paradise city Where the grass is green and the girls are pretty

Take me home (oh won't you please take me home)

The line "Take me Down the Paradise City' signifies the longing for experiencing freedom in life. Moreover, the phrase 'Take me Down' refers to hope and endeavor. The phrase 'Paradise City' carries the idea of a place to live. The narrator of the lyrics presumably represents young people, the age group whose members generally have a strong sense of frustration, desire, and hatred and therefore tend to have a strong attachment to rock $\mathrm{n}$ roll (Grossberg, 1983). The word 'Paradise' is defined as "a place or state of bliss, felicity, or delight" in Merriam-Webster Dictionary. The word is commonly associated with peacefulness and prosperity. Thus, it strongly suggests the idea that freedom originates in a peaceful and prosperous place.

The line "Where the Grass is Green and the Girls are Pretty" refers to the city and everything in it, while the phrase "Girls are Pretty' refers to the beautiful ladies living in that city. F. A Hayek states that "human beings are regarded to have the utter freedom if their personal space is guaranteed and free from the involvement of others as well as the repression from the government" (Miller, 2012).

People who are inspired by the idea of having free lifestyle will strive to make it come true. The phrase 'where the grass is green' emphasizes the idea of having a place to live. 
The word 'Green' has been characterized as 'fresh and new' (Merriam-Webster Dictionary). The word 'Green' is also associated with 'peace and prosperity, and this word suggests the hope of the society. In another context, Green is regarded as "an icon or visual representation that does not focus on existence, but on character and classification" (Spinks, 1991). 'Paradise City' underlines the idea of an ideal place that is symbolized by a beautiful lady who lives in peace and prosperity.

The strong desire of having freedom of expression can be the main reason for some individuals or groups of individuals to live in a city with the above mentioned description. It is about making a contribution with what they have in mind. The kind of freedom they wish for is a chance to perceive things in their own way and behave in the way they see right in the society. In this case, the prevailing conditions in the society determine the amount of freedom these young people can have in expressing what they have in mind without any repression.

Members of society have certain ways to search and find such freedom through their own ways of interpreting their surroundings. The word 'Paradise' functions as an index attached to an object. This index signifies the actual event or the object (Spinks, 1991). The phrase 'Paradise City' suggests a hope or an expectation to build a utopian city where the youths are able to live as they wish, free from any constrains.

Members of society always wish for both mental and physical freedom. Young people in particular tend to seek freedom in every aspect of their life, and young Americans are the clear example of this tendency. 'Paradise city' in the lyrics can be considered as the symbol of freedom in Americans' life. American youths feel the need to have a strong mindset to create their own freedom in the society they live in. In short, freedom is the fundamental reason for them to build such city.

Those members of society realize that they need to make tenacious efforts to improve the prevailing conditions. The line "Where the Grass is Green and the Girls are Pretty" implies the idea of building a new city and improving the quality of human life. The rules that deny certain groups and individuals to their rights must not be stipulated. People should live in harmony with each other and with their environment. The lyrics of this song suggest the notion that the city and the people living in it should protect each other.

The hardship in life also has shaped its inhabitants' personalities and their skill to survive. The line 'Take me Down the Paradise City' is also associated with childhood experience. In this sense, 'Paradise City' represents a peaceful and prosperous place to live. In this kind of city, human beings must talk and behave decently.

The phrase "Take me Home' describes that the narrators really want to live in the paradise city. 'Home' is defined as "one place of residence: Domicile" (Merriam-Webster Dictionary 1828). 'Home' in the lyrics refers to their current domicile, a city that is troubled with social conflicts. The social problem in the city has worsened into social unrest.

The phrase 'Take me Home' seems to highlight people's wish to live in a paradise city.It leads to an increasing sense of urgency to build a city in which social and cultural conflicts will never disturb its peace. "Take me Down the Paradise City" suggests the idea of living in a city where all parts of society can live and behave as they wish peacefully. 
The wish to have significant changes that help young Americans improve their personality becomes the main reason to have a better social environment. In relation to this idea, Guns N' Roses wrote a song that tells a story about childhood experience. It inspires young people in America to achieve freedom in living their life. By building a strong personality, they may be able to be the agents of new cultural development.

After the World War II, people in America have been inclined to seek freedom in life, and it is particularly apparent in the fights for civil rights. The youths have participated and are still participating in the struggles to have rights to live decently and respectfully in America.

The song titled 'Welcome to the Jungle' can be interpreted as the freedom that people in the society search for. It instills the idea that freedom is an indespensable part of human life. People should be free to choose the way they live their daily life. Whether or not people have freedom can be seen from their lifestyle. The word "Jungle" in the lyrics means "A place of ruthless struggle for survival' (MerriamWebster Dictionary 1828). 'Jungle' can be interpreted as a place where the young generation can live without constricting rules and pressures. In short, all groups in American society hope to live in such place since it gives them an opportunity to realize their dreams. The place is a new city where people can live without worries that their dreams will not come true.

Welcome to the jungle, we've got fun and games

We got everything you want honey, we know the names

We are the people that can find whatever you may need

If you got the money, honey we got your disease
The line "Welcome to the jungle, we've got fun and games" has a dual meaning. It represents the story of a young man coming to a big city and having experienced abuses in his childhood (Stenning, 2009). The part "we've got fun and games" describes his condition when living in the city. He struggles to survive in America while seeking freedom to express his mind and feeling. The lyrics as a whole tell the story of his life experiences as a young man who is trying to enjoy free lifestyle in the city.

Through the lyrics, the members of Gun $\mathrm{N}$ ' Roses are trying to tell people in general that it is possible to rebel and find a freedom to do as they wish. The lyrics pictures a society without any established rules. It encourages the society to change the improve conditions by allowing more freedom to speak and behave. This way is expected to free the society from the kinds of rules that put some individuals or groups in it at a disadvantage.

The narrator of the lyrics represents the youths' perspective on what is happening in the society. It is about how young people go through their own struggle to survive the hardship of living in the city. The phrase "Welcome to the jungle" connotes a group of young people who have to cope with the frustration of living in the city. They are determined to survive in Los Angeles.

The line saying "We got everything you want honey, we know the names, We are the people that can find whatever you may need" also describes what happens in the city. The city provides everything that people need, so it is easier for them to get their daily needs. The amenities of living in the city are the main factor that attracts young people to adapt to urban societies. This urban environment gives 
rise to a high hope or expectation in the young people.

Society has the power to create and develop mental and physical freedoms for its members. The extent of freedom allowed by a society determines how much the people in it can enjoy living in the city the way they want it. The line "We got everything you want honey" signifies the wish to live freely like living in the jungle. Sex and drugs are perceived as the embodiment of free lifestyle and are often associated with the lifestyle of subculture groups.

Some groups or individuals in society tend to express their freedom of speaking and behaving in their own way. They prefer to live in a social environment where there are no rules to control their actions. The song lyrics convey an observation that people prefer to live with the freedom of behaving and speaking the way they want it. It includes the way they dress and adorn themselves to express their identity.

Subcultural lifestyle is inseparable from the spirit of freedom. They have created their own freedom of expression the way they dream of. Freedom of expression is their way to establish their existence as part of a society, and their lifestyle is part of their distinctive characteristics. Members of youth subcultures mostly speak loudly and harshly. They like to have an intimidating appearance and listen to rock $\mathrm{n}$ roll. This preference of lifestyle had contributed to the development of rock $\mathrm{n}$ roll subcultures in the US.

Demonstrating free lifestyle undeniably causes certain risks. They wear all-black outfit and put tattoos on their body. Kang and Katheris explain that: "the youth subculture uses tattoo as the medium through which they show independence. Tattoo also gives the significant social influence to their own group" (2007, p. 42). It is believed that a tattoo conveys a message and in that case, it may serves as the symbol of freedom of expression. Tattoo, in their perception, shows their strong commitment to youth subculture with its resistance to the mainstream culture because one needs to be bold enough to tattoo or pierce one's body. In fact, tattoo and pierce symbolize their frustration and rebellion against the dominant culture.

The line "We are the people that can find whatever you may need" contains many layers of meaning that is associated with freedom, and its interpretation may vary for different social groups depending on the way they perceive freedom.The word "need" means "A lack of something requisite, desirable or useful" according to Merriam-Webster Dictionary. "Need" alludes to everything the city'Paradise' - has to offer which consists of spiritual and tangible needs. This urban abundance encourages the members of youth subculture to fulfill their needs.

This subculture believes that freedom can only be fully achieved if they separate themselves mentally and physically from the mainstream society. To fill in the gap they create as a consequence of detaching themselves from the majority, they use any way they can find to express themselves without restriction. In this way, they pave the way for a more pronounced social identity. Freedom of expression is also their means of resistance to the dominant culture in America.

\section{Subculture Groups' Resistance to the Mainstream Standard of Lifestyle}

American social groups have different ways of showing divergence or resistance to the mainstream culture. Writing meaningful 
lyrics for musicians can be a way if expressing such resistance. Through their lyrics, musicians can also offer their point of view about various social phenomena. Lyrics of rock $\mathrm{n}$ roll songs have a strong character with distinctive choice of words and lines. Paul Stenning argues that rock $\mathrm{n}$ roll music preserves its own myths simply by becoming myths, but these myths are reality (Stenning, 2009). Gun 'N Roses' song titled Sweet Child O' Mine refers to the myth of the band's life. It also signifies an interpretation of the life of subculture groups in America.

The members of Gun N' Roses express their resistance that is associated with their life experiences. They voice their struggle against violence and abuse as what happened to one of them in the past: I remember I was sexually abused by my stepfather and witnessed that something horrible happened to my mother when she picked me up (Stenning, 2009, p. 9). The phrase "Sweet Child" refers to childhood experiences of people in a youth subculture group. They had suffered from abuses since they were a child. It has been part of the social and cultural issues in the society.

The word 'Mine' implies that each member of Guns N' Roses has his stories of his life experience to share among them. With different backgrounds, each of them is a unique individual. Axl Rose, for example, has experienced domestic violence in his childhood. His father beat him whenever he did not do what his father told him to do (Stenning, 2009). This episode of life inspired him to write the lyrics for his song Sweet Child $O$ Mine. The lyrics of the song reveal how it feels to be a child who suffered abuses from a parent or both parents since very young, and to grow up affected by the trauma.
Gun N' Roses expresses all the feelings they experience while living in America. The episodes of their stories about it begin from their childhood. They reveal how they develop as a person with such traumatic upbringing. The lyrics of the mentioned song above deliver a message about domestic violence with children as the victim. The following excerpt of the lyrics allude to the life of a child living with such experience.

$\mathrm{Oh}$, oh, oh

Sweet child o' mine

Oh, oh, oh, oh

Sweet love of mine

The phrase "'Sweet child o' mine" is a child's expression of hatred towards his father who has conducted physical abuse to him and his mother. The word 'sweet' signifies the pain that the child had to endure throughout his childhood because of the abuse. This childhood experience has grown into resistance to the mainstream culture. Sweet Child O' Mine's lyrics communicates the idea that physical abusecan cause intense anxiety to the victim, and it is one of serious problems in American society. Indeed, mental and physical violence have been a troubling issue that American government should resolve.

Childhood experiences may have a significant effect on an individual as he/she grows up. Different nurtures will lead to different personality developments. For example, an individual who experienced abuses and violence during childhood would come to realize that he is different from other individuals who have normal childhood. The phrase 'Sweet child' in the lyrics connotes child abuse. Experiences with violence can be the main reason for an individual to express his resistance to it in his society. In larger scale, it also leads to the emergence of subcultures in the US. When they were little, Axl and his 
siblings were frequently beaten, If someone was beaten and got help from others so that the children could be free, often the punishment would be doubled (Stenning, 2009). They had witnessed violence and crime since their childhood. Therefore, they also fight against violence in their adulthood as a response to what they had experienced during their childhood.

One's personality develops and changes along with one'sconcern about social problems in one's surroundings. The phrase 'Sweet child' draws attention to the past events in life. Violence and abuses in the past are evidently still occurring in today's society, and along the way, subculture groups' resistance to the mainstream culture in America is growing. People from subculture groups continue to inspire the publicto express resistance against the social establishment. They value the courage to challenge the dominant society in America.

The lyrics of Sweet Love O' Mine can also be interpreted as one's expression of love towards oneself. In Merriam-Webster Dictionary, the word 'love' is defined as "affection based on admiration, benevolence, or common interests" (Merriam-Webster Dictionary). The word contains indexes related to the violence. "The index can represent itself but it is impossible to become the translator" (Spinks, 1991, p. 64). 'Love' is supposed to be defined as compassion for every human being. However, in the context of the lyrics, 'love' is related to the narrator's childhood experience. The singer, Axl Rose, once revealed that. Through the regression therapy, I reveal that my biological father, not my stepfather, has been sexually harassing me (Stenning, 2009). Thus, the song serves as a medium to portray what it is like to have a distressing childhood with the abusive experiences.

Children grow up with different behaviors since they have different experiences in their relationships with their parents. As children grow older, their wish to have freedom of speaking their mind and behaving is also growing. They will feel the need to tell others about their childhood experiences. The phrase 'sweet child o' mind' in the lyrics expresses the narrator's protective feeling against any violence or abuse in his social environment. Along the way, they are drawn towards free lifestyle as their response to the social conditions they have been experiencing and witnessing in their adulthood. Because of their support for the freedom of expression, they are motivated to support the rights of minority groups in America.

\section{She's got a smile it seems to me \\ Reminds me of childhood memories \\ Where everything \\ Was as fresh as the bright blue sky \\ Now and then when I see her face \\ She takes me away to that special place \\ And if I'd stare too long \\ I'd probably break down and cry}

The excerpt quoted above tells about a mother who tries to protect her child and fight for her rights. The story is related to violence as one of disquieting issues in the society. The line "She's got a smile it seems to me" is an expression of concern and protective feeling for the child's wellbeing. Although they have "frustration, desire, fear and hatred in adulthood, they give significant influences on the development to Rock n Roll" (Grossberg, 1984, p. 228). This song shows the band's deep concern for any individual who is physically and mentally abused. 
"She's got a smile it seems to me" can also be understood as an expression of hope for children's safety. It is a hope that the children who experience abuses will continue to survive as they grow up into adulthood, although they will never forget the violence they experience in their childhood. The line "Reminds me of childhood memories" refers to the past during which the narrator (me) suffered physical and mental abuses. He was treated like a slave in America: "Slaves were not allowed to write and read. Music and storytelling are crucial to communicate and to provide entertainment" (Yamasaki, 1996, p. 181). Child abuse causes psychological impacts on its victim.

A mother's ability to protect her children suggests the idea of her role in giving them a hope to survive and grow into adulthood. A child can make his mother's life much better. The line "Was as fresh as the bright blue sky" represents a beautiful past when the narrator still had the chance to enjoy his life. However, he also has a strong will to fight violence in the society. The phrase 'Bright Blue' can be interpreted as one's ideals. An individual can fulfill his ideals through his struggle against the social establishment since he was a child. However, for subculture groups, violence will always be a major issue. Moreover, "the more adults emphasize the uniqueness of their children, the more they are frustrated and feeling insecure" (Grossberg, 1984).

Young people have shown positive changes in their attention to social and cultural issuesin their surroundings. They also express their opposition to violence that frequently occurs in America; some of which are related to crime and racism. This concern for violence is expressed through rock $\mathrm{n}$ roll songs. Indeed, "music disperses and crosses categories such as identity, community group, nationality" (Love,
2018). Guns N' Roses' Sweet Child O' Mine describes the struggle of challenging the established ways of interacting with others in society. The song is one of the ways the band expresses their care for the victims of physical and mental abuses in America.

Lawrence Grossberg explains that "Rock n Roll strength lies on its effectiveness, such as its ability to produce and regulate the structure of desire. However, the effort to regulate wish is associated with the clash between resistance and kinship" (Grossberg, 1983, p. 104). The line "I'd probably break down and cry" is the expression of sorrow because of an abusive childhood. Every teenager wants to resist violence he/she has experienced in his/her childhood. They want to emphasize the different effects between affection and abuse on children's psychological health. Unfortunately, many people have to go through hard times in the past because they live in parts of the city with hostile social environment.

Abusive childhood can lead to adverse psychological and physical changes. Children with abusive experiences may grow up to be a person with extreme personality: "They had been in prison for 10 days in 1980 . He received punishment due to beating people, committing crimes as a result of being drunk, trespassing people's residence without permission, and having bad attitude" (Stenning, 2009). They will feel the urge to be free from constricting rules in American society. They will want to express their strong opposition to violence and wickedness in society as well as their support for free lifestyle.

She's got eyes of the bluest skies

As if they thought of rain

I hate to look into those eyes

And see an ounce of pain

Her hair reminds me of a warm safe place

Where as a child I'd hide 
And pray for the thunder

And the rain

The lines "Her hair reminds me of a warm safe place" and "where as a child I'd hide" tell the listeners about a mother's effort to protect her children's ideals. The word 'warm' refers to a sense of comfort of being protected by amother. The mother is the only person that her children can trust. Consequently, they grow to be rebellious individuals for the lack of trust for the unsupportive social establishment in their surroundings. Anti-establishment attitude is generally apparent in the minority groups that fight for equal rights in the US. They rebel against the mainstream culture in society.

The line "where as a child I'd hide" suggests fear during childhood. It represents the feeling of a person who could only hide from everything he is afraid of when he was very young. The overall message reveals the narrator's determination to formalize his resistance to the dominant culture, the attitude he has been developing since childhood. It connects an individual's past to his future. "Music is a communicative interaction through materials and tools of "sound" (Fornas, 1980, p. 294). Sweet Child O' Mine's lyrics convey an observation about a social issue that is related to dysfunctional childhood.

One's experiences with violence during childhood cannot be forgotten, and the victim will carry its impact to his adulthood. "The child abuse has emerged and refers to personal action" (Hearn, 1988, p. 33). Traumatic childhood experience with violence may be a trigger for crimes. Violence harms children's psychological development and may prevent them from improving their life conditions. As a result, they grow up with the spirit to resist and to be free from the unsupportive social establishment.
Violence can affect an individual's mental health and may also make him develop harsh and cruel behavior. It prompts awareness that violence must be responded with resistance. The word 'pain' in Merriam Webster Dictionary means "mental or emotional distress of suffering". In the context of the lyrics, it represents mental and physical pain. It encourages people to stand up to the negative parts of the society. The message is that a young man must be a reformer in the society. The pain one experiences in because of his parent's mistreatment can leave lasting impact with the lingering wound that he has to heal himself his lifetime. Violence can create a defective phase in one's life. The 'pain' in the lyrics refers to the impact of the violence (abuse) conducted by people that is closest to the victim.

Gun N' Roses songs such as Sweet Child $O$ ' Mine can be regarded as an evidence of this band's existence in America. Through the song, Guns N' Roses tries to warn their listeners that mental and physical violence can happen anywhere. The song's lyrics emphasizes that violence can have a damaging impact on the victim's psychological conditions. He may have to struggle his whole life to be free from his wound from the past. He may have to constantly seek redemption for his traumatic childhood.

The line "And pray for the Thunder, And the rain" metaphorically signifies the narrator's determination to continue to live his life and express resistance to violence in America. The word 'pray' in Merriam Webster Dictionary is defined as "to make a request in a humble manner". In the lyrics, 'pray' refers to an effort to counter violence besides concrete actions such as expressing ideas and attitude against it openly. 
Young people can inspire their social environment with the spirit of resistance. They have their own ways of taking part in such effort. Indeed, many of them have demonstrated their strong will to change the prevailing perspective on subculture groups. The youths become the agent of change by openly expressing what they feel and think.

The line "I see your sister in her Sunday dress" in It's So Easy lyrics suggests what many people think about women's behavior in America. Women are believed to be responsible for causing progress as well as setbacks in major cities. From this stand point, some cities which enjoy rapid development are associated with the way they position women in the society. Women are seen to belong to subculture group. They are often treated as the object of sexual attention. Yet, they are also the source of inspiration for musicians as they often write lyrics about women. Women are welcome enthusiastically by the youths in subculture groups. They are given plenty of chance to participate and contribute to subculture development. This dynamic social relationship contributes to the Guns N' Roses' creativity and productivity in writing their lyrics.

Gun N' Roses' songs have an undertone of resistance to the dominant social order. Through their lyrics, the band set a pattern or trend of cultural expression that is different from the established culture. Therefore, freedom of expression embodies the hope for the subculture group and builds the group's identity. The line "she's out to please" suggests that certain subculture groups think of women asthe object of sexual desire. Their attitude towards women is often harsh and degrading.
Each member of Gun N' Roses makes his own contribution to the lyrics of the songs in their album. The lyrics often show direct criticism to the policies that only favor the majority. Biased policy can make some people's lives harder. Gun N' Roses' songs express concern for the minority who is negatively impacted by such policies. In this way, they encourage minority groups to fight for their rights.

The line "no need to try" signifies a resistance to the mainstream culture. The mainstream culture often constricts young people who need larger space to express themselves. As a response to this constriction, they actively comment on the prevailing social issues in America such as inequality in civil rights in America. People are supposed to have equal opportunity to express their own aspirations.

Subculture groups try to fight physical and mental violence in the society. Therefore, subculture groups tend to demand for the formation of alternative cultures that are initiated by minority groups. The following excerpt from It's So Easy lyrics express subculture group's opposition to the mainstream culture.

It's so easy, easy
When everybody's tryin' to please me baby
It's so easy, easy
When everybody's tryin' to please me
Cars are crashin' every night
I drink n' drive everything's in sight
I make the fire
But I miss the firefight
I hit the bull's eye every night
In 'It is So Easy" there is the word 'easy'
that functions as an icon for the effort made by
the people in resistance. It alludes to a renewed
sense of excitement for struggle among the
minority groups in America. It is the struggle 
to confront physical and mental violence that have hurt many people since they were young.

In their attempt to respond to the social issues in American society, subculture groups have actively participated in resisting violence of any kind. Their efforts have also inspired other groups to fight violence acts in the society. The word 'easy' suggests that the effort is not difficult. It feels easy for them to act to resist violence despite social pressures from their surroundings if they do it together with other members of society.

The line "cars are crashin' every night" in the lyrics is related to youngsters who spend the night expressing their opposition to the dominant culture. The word 'night' refers to "an evening set aside for a particular purpose" (Merriam Webster Dictionary). In another sense, 'night' connotes one group's distinction from other groups. It has more activities at night than in the morning. This pattern shows the group's inclination towards the freedom of behaving in ways they feel right.

The word 'night' is also an adverb of time that indicates when the group activities in question take place. So, the song writer uses this word to tell that those activities happen at night. It is the time when the members of the group consolidate their agenda. In addition, as mentioned previously, 'night' emphasizes the distinctive characteristic of the group. Thus, it can be concluded that Guns N' Roses' lyrics present subculture as a form of resistance to the mainstream culture.

\section{CONCLUSION}

Gun N' Roses' song lyrics have given abig influence on American public in particular and the global world in general. They express hope for freedom in life as a member of a society.
An individual can have his freedom by choosing his own way of speaking and behaving for particular reasons. One of the reasons can be a resistance to cope with the troubling past experiences. The search for freedom of expression is the theme of Guns N' Roses' album titled Appetite for Destruction.

The freedom in expression and action of subculture groups can be observed in the way they survive the urban life. They always show their anti-mainstream attitude. The lyrics on the songs in Appetite for Destruction reflect the life of subculture groups. The reason of their actions is their experiences as the victims of mental and physical abuses in their childhood.

Subculture groups' resistance is closely related to the violence they had to face in the past. They fight against violence in order to survive in their adulthood in the society where they are situated. Apart from that, subculture groups play a role of creating new or alternative cultures in the society. The song lyrics in the album can be regarded as a portrayal of how the members of subculture groups live their free lifestyle. For example, they have tattoos and pierces to express themselves, and they are also accustomed to sex, drugs, and alcohol. These are the ways they express their freedom in living their life.

Subculture groups fight against the mainstream culture in American society. They do their activities on the street as grownups while struggling to live independently in America. This is the way that subculture groups choose to survive in contemporary society.

The violence which most members of the groups experience throughout their life becomes the reason why they show resistance to the dominant culture. They develop their 
own peculiar behavior. They often speak rudely and loudly to confront violence they encounter in their surroundings. They make their own efforts to fight physical and mental violence. This becomes their style of rebelling against the mainstream culture in their life.

\section{REFERENCES}

"Meriam Webster Dictionary." (1828). Retrieved January 13, 2020, from https://www.merriamwebster.com/dictionary/pray

"Meriam Webster Dictionary." (1828). Retrieved January 13, 2020, from https://www.merriamwebster.com/dictionary/street

"Meriam Webster Dictionary." (1828). Retrieved January 13, 2020, from https://www.merriamwebster.com/dictionary/pain

“Meriam Webster Dictionary." (1828). Retrieved January 13, 2020, from https://www.merriam-

webster.com/dictionary/green

"Meriam Webster Dictionary." (1828). Retrieved January 13, 2020, from https://www.merriam-

webster.com/dictionary/money

“Meriam Webster Dictionary." (1828). Retrieved January 13, 2020, from https://www.merriamwebster.com/dictionary/need

"Meriam Webster Dictionary." (1828). Retrieved January 13, 2020, from https://www.merriamwebster.com/dictionary/jungle

"Meriam Webster Dictionary." (1828). Retrieved January 13, 2020, from https://www.merriamwebster.com/dictionary/love
"Meriam Webster Dictionary." (1828). Retrieved January 13, 2020, from https://www.merriam-

webster.com/dictionary/free

"Meriam Webster Dictionary." (1828). Retrieved January 13, 2020, from https://www.merriamwebster.com/dictionary/charity

Creswell, John W. (2009). Research Design: Qualitative, Quantitative and Mixed Method Approaches. United Kingdom: SAGE Publication.

F. Miller, Eugene. (2012). Kondisi Kebebasan Liberalisme Klasik F.A Hayek. Jakarta: Freedom Institute.

Fornas, Johan. (1990). Moving Rock: Youth and Pop in Late Modernity. 291-306. Cambridge University Press.

Grossberg, Lawrence. (1984). Another Boring Day in Paradise: Rock and Roll and the Empowerment of Everyday Life. 225-258. Cambridge University Press.

Grossberg, Lawrence. (1983-1984). The Politics of Youth Culture: Some Observations on Rock and Roll in American Culture. 104-126. Duke University Press.

Hearn, Jeff. (1988). Commentary. Child Abuse: Violences and Sexualities toward Young People. 531-544. Sage Publications, Ltd.

Hebdigie, Dick. (1979). Subculture The Meaning of Style. London and New York: Routledge Taylor \& Francis Group.

Jones, Miliann Kang and Katherine. (2007). Why Do People Get Tattoos?. 42-47. Sage Publications.

Koskof, Ellen. (2005). Music Culture in the United States. New York: Routledge. 
Love, Nancy S. (2018). From Settler Colonialism to Standing Rock. 1-16. College Music Society.

Moore, Jerry D. (2009). Vision Of Culture. USA: Alta Mira Press.

Purcell, Natille J. (2003). Death Metal Music the Passion and Politics of a Subculture. North Carolina: Mcfarland \& Company Publishers.

Rowe, John Carlos. (2000). Post-nationalist American Studies. Berkeley and Los Angeles, California: University of California Press.

Spinks, C. W. (1991). Peirce and Triadomina. New York: Mouton de Gruyter.
Starr, Lary Chirstoper Waterman. (2006). American Popular Music The Rock Year. New York: Oxford University Press.

Stenning, Paul. (2009). Band yang Dilupakan Waktu Biografi Lengkap Gun N Roses. Yogyakarta: Ayyana.

Sugihartati, Rahma. (2017). Budaya Populer dan Subkultur Anak Muda: Antara Resistensi dan Hegemoni Kapitalisme di era Digital. Surabaya: Airlangga University Press.

Yamasaki, Mitch. (1996). Using Rock 'N' Roll to Teach the History of Post-World War II America. 179-193. Society for History Education. 